\title{
Practical Aspects of Twin Pregnancy Diagnosis in Cattle
}

\author{
Zoltán Szelényi ${ }^{1}{ }^{*}$, Ottó Szenci ${ }^{1}$, Levente Kovács ${ }^{2}$ and Irina Garcia-Ispierto ${ }^{3} \mathbb{C}$ \\ 1 Department of Obstetrics and Food Animal Medicine Clinic, University of Veterinary Medicine, \\ 1078 Budapest, Hungary; Szenci.Otto@univet.hu \\ 2 Institute of Animal Sciences, Hungarian University of Agriculture and Life Sciences, 7400 Kaposvár, Hungary; \\ Kovacs.Levente@uni-mate.hu \\ 3 Agrotecnio Center, Animal Science Department ETSEA, University of Lleida, 25198 Lleida, Spain; \\ Irina.Garcia@udl.cat \\ * Correspondence: Szelenyi.Zoltan@univet.hu; Tel.: +36-30-296-7012
}

\section{check for}

updates

Citation: Szelényi, Z.; Szenci, O.; Kovács, L.; Garcia-Ispierto, I. Practical Aspects of Twin Pregnancy Diagnosis in Cattle. Animals 2021, 11, 1061. https://doi.org/10.3390/ani11041061

Academic Editor: Rafael Bisinotto

Received: 15 March 2021

Accepted: 6 April 2021

Published: 8 April 2021

Publisher's Note: MDPI stays neutral with regard to jurisdictional claims in published maps and institutional affiliations.

Copyright: (c) 2021 by the authors. Licensee MDPI, Basel, Switzerland. This article is an open access article distributed under the terms and conditions of the Creative Commons Attribution (CC BY) license (https:/ / creativecommons.org/licenses/by/ $4.0 /)$.
Simple Summary: This review summarizes the clinical background, possibilities, and limitations of twin pregnancy diagnosis in cattle, with a special emphasis on pregnancy loss aspects. Due to the fact that reproductive performance is strongly affected by twin pregnancy, clinical veterinarians should become familiar with the correct diagnosis of this phenomenon. Thus, each herd must plan a herd-specific management practice to detect twin pregnancies. A highly accurate diagnostic tool is required to detect such pregnancies, already during the first month of gestation. This commentary review focuses on the diagnostic possibilities and limitations on the field.

\begin{abstract}
Twin pregnancies are an economically unwanted phenomenon in dairy cattle, not only because they increase pregnancy losses, but also because antibiotics usage and culling rate of the dam are also dramatically increased due to them, furthermore animal welfare issues are also affected through them. In cattle, under field conditions using an early pregnancy determination tool, the first accurate diagnosis from the pregnancy status is available from around day 28, although further confirmations of pregnancy are required. Twin pregnancy diagnosis is available either by rectal palpation or ultrasonography. The measurement of pregnancy specific proteins are also available to determine gestation, but there is still a long way to go to properly identify twin pregnancies. In this commentary, we compared our own results with the literature data in this field with a special emphasis on the clinical practices.
\end{abstract}

Keywords: cattle; PAG; pregnancy loss; PSP-B; rectal palpation; twin; ultrasound

\section{Introduction}

The diagnosis of twin pregnancy is one of the key factors for reproductive performance in well managed dairy herds. Among the undesirable consequences are higher percentage of pregnancy losses [1-4], shorter duration of gestation, increased stillbirth and dystocia rates [5-7], and increased frequency of postpartum complications (retained placenta, metritis), and consequently the increase of the use of antibiotics $[6,8]$ should be mentioned. Twin pregnancy also has negative consequences on the newborn calves (decreased birth weight, increased mortality) [8]. Another disadvantage is freemartinism [9], due to sex chromosome chimerism resulting in grossly abnormal internal genitalia of freemartin heifers [8,10]. Twin pregnancy also shortens the length of gestation [8,11].

Earlier observational data in Hungary including more than 13,000 calvings in five years reported a $3.4 \%$ incidence rate of twin pregnancies [12], with a maximum of eight to nine percent in some years [7,12] at calving time. A much higher twin pregnancy rate can be found at the time of pregnancy diagnosis. A study from Spain reported 20\% twin pregnancy rate at the time of ultrasound pregnancy diagnosis, at the end of the first month of gestation [13]. The same study reported an increased frequency of unilateral 
twins. However, our own data [14] showed an almost equal distribution of unilateral and bilateral twins.

A recent Hungarian study [15] highlighted that about $70 \%$ of the dairy farms introduced some technological tool to detect early pregnancy. Another study from the United Kingdom reported more common application [16] and highlighted the importance of evaluation the pregnancy diagnosis. However, in Hungary about one third of the farms still use rectal palpation to detect pregnancy diagnosis. For that reason, nowadays there are no data about regular screening for twin pregnancy.

\section{Clinical Diagnosis of Twin Pregnancy}

During the last four decades, the rate of twin calving has increased [1,17] due to the increase of multiple ovulations associated with high milk yield $[13,18]$ and with the use of different synchronization protocols [2]. Double ovulation occurs more frequently in multiparous cows with high milk production than in primiparous cows $[13,18,19]$.

A recent study advised to set up 'pivotal periods', by taking into consideration the practical point of view of the regular reproductive management possibilities. Under field conditions, the application of an early pregnancy determination tool as the first accurate diagnosis is available from around day 28 , and further confirmations of pregnancy are required [20]. In our own previous study, pregnancy diagnosis was carried out between days 29 and 42, with an average of day 33.6 [21].

It seems that fulfilment of the metabolic requirements of high-yielding cows stands behind double ovulations (during the first 8 weeks of lactation when milk production peaks). In a study [13], cows above a milk production of $50 \mathrm{~kg} /$ day showed a rate of multiple ovulations higher than 50 percent.

\subsection{Rectal Palpation}

Pregnancy diagnosis can be performed in several ways, such as palpation of the amniotic vesicle [22]. The vesicle(s) of about $1-2 \mathrm{~cm}$ in diameter can be palpated on the same side where the ovaries carry the corpora lutea. Experienced practitioners can palpate the amniotic vesicle as early as on day 30 of pregnancy. The other possibility for palpating pregnancy is the technique of fetal membrane slipping. It is not commonly used in Europe, while it is more widely applied in the United States [23].

Most of these techniques carry the risk of damaging the amniotic vesicle [24-28]. According to Day et al. [29] and Karlsen et al. [30], rectal manipulation carries the highest risk of damaging the embryo. The general pregnancy loss in the above-mentioned reports varied between $3 \%$ and $10 \%$. Romano [23] examined cows in early gestation by ultrasonography, and then also used the fetal membrane slipping technique between days 34 and 41 of pregnancy. It was found that repeated ultrasound examinations-when carrying out the confirmational examination with ultrasound-did not increase the pregnancy loss. When analyzing the data of all cows giving data to the study, the total pregnancy loss ratio was $14 \%$. It was concluded that the increased number of rectal palpations and/or the possible endogenous release of prostaglandins might have contributed to this.

In Hungary, palpation of fluctuation in the pregnant uterine horn is widely used at days 42-48 of pregnancy [15]. Positive pregnancy diagnosis due to the accumulation of allantoic fluid means an enlarged/asymmetric pregnant uterine horn, while experienced practitioners can successfully perform this examination already between days 30 and 40 of gestation $[23,31]$; however, pathologic conditions such as pyometra and metritis will present the same signs; therefore, this method should never be used as a stand-alone pregnancy diagnosis method [28].

By rectal palpation, bilateral twins can be detected by enlargement of the uterine horns. On the contrary, unilateral twin pregnancies remains unnoticed. For these reasons, rectal palpation cannot be used as a routine screening technique of twin pregnancies.

Concerning twins, a result of the ovulation of co-dominant follicles [30] two corpora lutea (CL) are formed, and two embryos will start to develop in the uterine horn(s). The 
occurrence of monozygotic twins, originating from a single ovulation and spontaneous division of the embryo, is rare, around 5\% among all twins [32]. Triplets or higher-order twins are extremely rare in cattle. Although two CL can be present on the same ovary (meaning usually two embryos in the same uterine horn), bilateral twins are more common than unilateral ones, therefore the presence of two CL not necessarily means twins, while double ovulations are much more common than twin pregnancy [13].

\subsection{Transrectal Ultrasonography (TRUS)}

Ultrasonography was first introduced into bovine reproduction management in the 1980s. Curran et al. [33] determined the times when different fetal organs of the embryo could be detected. In their study, embryonic heartbeat was detectable as early as on days 22-24 post AI. Nowadays, this is the diagnostic criterion for a positive pregnancy diagnosis. It is difficult to evaluate fetal heartbeat at that early stage in practice, therefore the most implemented period to diagnose pregnancy with transrectal ultrasonography is between 28-35 days of gestation. [34-36]. The allantoic fluid is first visible from days 25-26 in multiparous cows and from days 23-24 in heifers [23]. Furthermore, the presence of the embryo and the active heartbeat are the main criteria for a positive early pregnancy diagnosis by means of TRUS under practical conditions. As regards the location of the embryos, they can be located either unilaterally or bilaterally, unilateral twins used to have an echogenic line connecting the two embryos, acting as a diagnostic tool [10].

In the case of twin pregnancy, both embryos heartbeats, and the amniotic vesicles should be detected in TRUS examination [37]. In case of doubts in twinning or fetus viability, the evaluation of ovarian structures could be assessed: (1) Number, usually two (30) due to the fact that mostly of twin pregnancies come from the ovulation of co-dominant follicles not from monozygotic twins [38]; (2) Quality of CL, meaning that the echogenicity and the size of the $\mathrm{CL}$, which should be at least $17 \mathrm{~mm}$ in the largest diameter [39]. Our data confirmed this [14]; furthermore, we found a low number of twin pregnancies with three corpora lutea. The proportion of cows carrying singleton pregnancies with two corpora lutea was around $10 \%$. With the diagnostic possibilities, it is hard to differentiate between singleton pregnancies and a co-dominant pregnancy or a possible partial embryonic mortality [40].

\subsection{Examination of Pregnancy Proteins}

From day 22 of pregnancy, mononuclear cells originating from the trophoblast migrate into the endometrium. Cell migration originating from the trophoblast can be observed throughout the gestation. During this process, they turn into binucleate and, in some cases, trinucleate cells. Because of this migration, the bovine placenta is called a synepitheliochorial placenta [41,42].

Pregnancy-associated glycoproteins can be differentiated into two subgroups: the PAG2 subgroup [43] was known to mainly be localized at the fetal-maternal borderline, although some reports recently showed them in the maternal plasma [44,45]. The PAG-1 subgroup is expressed mostly on the bi- and trinucleate cells of the trophoblast, although mononucleate cells also secrete it $[46,47]$. The measurement of them was used to discriminate singleton and twin pregnancies [48]. Molecular cloning studies showed that the amino acid sequence of PSP-B is homologous to that of PAG1, and they are inactive members of the aspartic acid proteinase family [49]. The isolated preparations differed in carbohydrate and sialic acid content. These characteristics may explain the minor differences in their profile and in their disappearance from the maternal circulation after calving or embryonic mortality [50].

Despite 30 years of intensive research, the clear function of the production of these proteins has remained unknown. The welfare and viability of the fetus, as well as pregnancy loss during gestation, can be monitored by their use $[45,48,50]$

For more than 20 years, different methods were used for measuring pregnancy proteins: blood sera [51] and milk [52,53]. Serum is the method of election because these proteins have lower concentrations in milk [20]. Besides the biological fluid, numerous 
factors may affect the concentrations of pregnancy proteins in serum. Yániz et al. [54] showed significant differences in PAG-1 levels between individuals depending on the sire, the number of embryos, and the season.

Several studies showed that in dams carrying two embryos, higher concentrations of PAG-1 could be measured, and with the progress of gestation, the elevation of PAG-1 concentration was also higher than in cows carrying singletons $[55,56]$. Despite this, PAG-1 cannot identify partial pregnancy loss or embryo reduction [56]. Moreover, the shorter half-life of PAG compared to PSP-B is also remarkable [57]. One study determined that TRUS is needed for twin pregnancy diagnosis [58] because clinically applicable cut-off value for the diagnosis of twin pregnancy could only be reached from day 85 of pregnancy.

\section{The Effect of Twin Pregnancy on Pregnancy Losses under Practical Conditions}

There are several factors influencing the pregnancy loss associated to twin pregnancy. One of the most important factors is the embryo's location in the uterus. Bilateral twin pregnancies resulted in a lower number of pregnancy losses than unilateral twin pregnancies [56], indicating that possibly the physical extensions of two embryos can induce pregnancy loss. Heat stress effect was studied to influences pregnancy losses of dams pregnant with twins [32], and in another study, heat stress also effected pregnancy loss with the same odds as carrying a twin pregnancy [59]. The method of pregnancy diagnosis can also be a source of pregnancy loss; however a recent study, when veterinary students under training were performing rectal palpation [60], could not confirm this. In case of increased losses after early pregnancy diagnosis, to date there is no data and most of the recent scientific results supported the ineffectiveness of the careful examination.

The primary pregnancy diagnoses must be confirmed later $[20,56,61]$ to achieve reliability and to manage herd health issues. This confirmation is usually performed around day 60 of pregnancy when placentation is completed [24]. Most of the losses in singleton and twin pregnancies usually occur between the time of early pregnancy diagnosis and the confirmation of gestation [20,62]. Twin pregnancy loss also showed a peak in late gestation [14].

\section{Management of Twin Pregnancies}

The individual animal performing of induced reduction in case of twin pregnancy is a described method $[63,64]$. The manual embryo reduction is considered to be the most economic option to mitigate the negative impacts of twinning [65]; however, practical application is not widespread at the moment. The maintaining strategy is based on medical treatments [66] highlighting that the economic circumstances must be taken into consideration as well. The total herd level termination of twins by using prostaglandin F2alpha is a possible strategy [67], but farmers' resistance should be noted when performing it under practical circumstances. In dairy herds with low incidence rate of twinning, termination of pregnancy can be an option.

In case of a dairy herd, the early diagnosis of twin pregnancies is the primary goal. Previously, it was shown in two independent studies under practical circumstances [14,68], that the application of different synchronization protocols prior AI decreased the percentage of the occurrence of twinning. The possible explanation was that the stronger regulation of the ovarian cycle was decreasing the possibility of the ovulation of coordinated follicles [67]. An alternative solution at herd level can be the screening for twins at the early diagnosis with a selected diagnostic method, after that the identified twins undergo confirmational diagnosis every second week until day 60 of pregnancy in order to rule out partial or total losses. At the time of the initial twin diagnosis, medical support should be given. It was also demonstrated in clinical practice, that calving time stillbirth events dramatically increase due to twinning [14], therefore careful management in the calving barn is also part of the defense on one hand, with the training of the assistance to handle twin calvings and on the other hand to support the newborn animals. 


\section{Conclusions}

Based on the data presented above, nowadays all the pregnancy examination methods seem to be feasible in detecting twin pregnancies in dairy cows. The rectal palpation is able to distinguish between unilateral and bilateral twin pregnancies. Transrectal ultrasonography is the most widespread method under practical circumstances, because both unilateral and bilateral twins can be detected. Moreover, heartbeat (and through this fetal viability) and corpora lutea can be monitored. The measurement of pregnancy-specific proteins from biological fluids has been a promising tool for 20 years, but at the moment, the detection of twins is limited. Further studies should be performed in order to increase the accuracy of this technique.

Pregnancy loss also affects reproductive performance with special regard to twin gestations in cattle. While more authors demonstrated an increased occurrence of losing twin pregnancies, especially in the case of unilateral twins, the distribution of laterality shows high variability, resulting under field circumstances various results.

Author Contributions: Z.S.—writing—original draft preparation, O.S.—review and editing L.K.review and editing, funding acquisition, I.G.-I.-writing-review and editing, supervision. All authors have read and agreed to the published version of the manuscript.

Funding: Levente Kovács was supported by the OTKA Research Scholarship of the National Research, Development and Innovation Office (Budapest, Hungary; K-134204) and by the NTP-NFTÖ-20 project by the Human Capacities Grant Management Office and the Hungarian Ministry of Human Capacities, Budapest, Hungary (NTP-NFTÖ-20-B-0030).

Acknowledgments: The authors would like to thank Fernando López-Gatius, György Gábor and Orsolya Varga-Balogh for their support.

Conflicts of Interest: The authors declare no conflict of interest.

\section{References}

1. Del Río, N.S.; Stewart, S.; Rapnicki, P.; Chang, Y.M.; Fricke, P.M. An observational analysis of twin births, calf sex ratio, and calf mortality in holstein dairy cattle. J. Dairy Sci. 2007, 90, 1255-1264. [CrossRef]

2. Andreu-Vázquez, C.; Garcia-Ispierto, I.; Ganau, S.; Fricke, P.; López-Gatius, F. Effects of twinning on the subsequent reproductive performance and productive lifespan of high-producing dairy cows. Theriogenology 2012, 78, 2061-2070. [CrossRef] [PubMed]

3. Spitzner, Á.; Németh, T.; Egerszegi, I.; Balogh, O.; Kern, L.; Gábor, G. Occurrence of twin pregnancy and calving and its effect on reproduction in ruminants. Literature review. Hung. Vet. J. 2013, 135, 595-608.

4. Gábor, G.; Kastelic, J.P.; Abonyi-Tóth, Z.; Gábor, P.; Endrődi, T.; Balogh, O.G. Pregnancy loss in dairy cattle: Relationship of ultrasound, blood pregnancy-specific protein b, progesterone and production variables. Reprod. Domest. Anim. 2016, 51, 467-473. [CrossRef] [PubMed]

5. Nielen, M.; Schukken, Y.; Scholl, D.; Wilbrink, H.; Brand, A. Twinning in dairy cattle: A study of risk factors and effects. Theriogenology 1989, 32, 845-862. [CrossRef]

6. Beerepoot, G.M.M.; Dykhuizen, A.A.; Nielen, Y.; Schukken, Y.H. The economics of naturally occurring twinning in dairy cattle. J. Dairy Sci. 1992, 75, 1044-1051. [CrossRef]

7. Ari, M.; Orbán, M.; Janbaz, J.; Szúcs, E.; Kovácsné Gaál, K.; Gulyás, L. Twin calving in Hungarian Holstein-friesian herds. Hung. Vet. J. 2011, 133, 396-402.

8. Echternkamp, S.E.; Gregory, K.E. Effects of twinning on gestation length, retained placenta, and dystocia. J. Anim. Sci. 1999, 77, 39-47. [CrossRef]

9. Wijeratne, W.V.; Munro, I.B.; Wilkes, P.R. Heifer sterility associated with single-birth freemartinism. Vet. Rec. 1977, 100, 333-336. [CrossRef]

10. López-Gatius, F.; Andreu-Vázquez, C.; Mur-Novales, R.; Cabrera, V.E.; Hunter, R.H.F. The dilemma of twin pregnancies in dairy cattle. A review of practical prospects. Livest. Sci. 2017, 197, 12-16. [CrossRef]

11. Norman, H.D.; Wright, J.R.; Kuhn, M.T.; Hubbard, S.M.; Cole, J.B.; VanRaden, P.M. Genetic and environmental factors that affect gestation length in dairy cattle. J. Dairy Sci. 2009, 92, 2259-2269. [CrossRef]

12. Boldizsár, S.Z. Occurrence, Diagnostics and Features of Twin Pregnancy in Dairy Cattle. Ph.D. Thesis, SZIU-FVSC, Budapest, Hungary, 2009.

13. López-Gatius, F.; López-Béjar, M.; Fenech, M.; Hunter, R. Ovulation failure and double ovulation in dairy cattle: Risk factors and effects. Theriogenology 2005, 63, 1298-1307. [CrossRef]

14. Szelényi, Z.; Győri, D.; Boldizsár, S.; Kovács, L.; Répási, A.; Molnár, L.; Szenci, O. Pregnancy and stillbirth losses in dairy cows with singleton and twin pregnancies. Acta Vet. Hung. 2019, 67, 115-126. [CrossRef] 
15. Fodor, I.; Búza, L.; Ózsvári, L. Main reproductive parameters and reproductive management indices of large scale dairy herds in Hungary. Hung. Vet. J. 2016, 138, 653-663.

16. Tzelos, T.; Howes, N.L.; Esteves, C.L.; Howes, M.P.; Byrne, T.J.; Macrae, A.I.; Donadeu, F.X. Farmer and veterinary practices and opinions related to fertility testing and pregnancy diagnosis of UK dairy cows. Front. Vet. Sci. 2020, 7, 7. [CrossRef]

17. Kinsel, M.; Marsh, W.; Ruegg, P.; Etherington, W. Risk factors for twinning in dairy cows. J. Dairy Sci. 1998, 81, 989-993. [CrossRef]

18. Fricke, P.M.; Wiltbank, M.C. Effect of milk production on the incidence of double ovulation in dairy cows. Theriogenology 1999, 52, 1133-1143. [CrossRef]

19. Kusaka, H.; Miura, H.; Kikuchi, M.; Sakaguchi, M. Incidence of double ovulation during the early postpartum period in lactating dairy cows. Theriogenology 2017, 91, 98-103. [CrossRef]

20. Wiltbank, M.C.; Baez, G.M.; Garcia-Guerra, A.; Toledo, M.Z.; Monteiro, P.L.; Melo, L.F.; Ochoa, J.C.; Santos, J.E.; Sartori, R. Pivotal periods for pregnancy loss during the first trimester of gestation in lactating dairy cows. Theriogenology 2016, 86, 239-253. [CrossRef]

21. Szelényi, Z.; Bajcsy, Á.C.S.; Horváth, A.; Simon, J.; Szenci, O. Evaluation of a complex reproductive management in a large-scale Holstein-Friesian dairy farm. Hung. Vet. J. 2010, 132, 529-536.

22. Wisnicky, W.; Cassida, L.E. A manual method for diagnosis of pregnancy in cattle. J. Am. Vet. Med. Assoc. 1948, $113,451$.

23. Romano, J.E.; Thompson, J.A.; Kraemer, D.C.; Westhusin, M.E.; Forrest, D.W.; Tomaszweski, M.A. Early pregnancy diagnosis by palpation per rectum: Influence on embryo/fetal viability in dairy cattle. Theriogenology 2007, 67, 486-493. [CrossRef]

24. Ball, L.; Carroll, E.J. Induction of fetal death in cattle by manual rupture of the amniotic vesicle. J. Am. Vet. Med. Assoc. 1963, 142, 373-374.

25. Paisley, L.G.; Mickelsen, W.D.; Frost, O. A survey of the incidence of prenatal mortality in cattle following pregnancy diagnosis by rectal palpation. Theriogenology 1978, 9, 481-491. [CrossRef]

26. Franco, O.; Drost, M.; Thatcher, M.-J.; Shille, V.; Thatcher, W. Fetal survival in the cow after pregnancy diagnosis by palpation per rectum. Theriogenology 1987, 27, 631-644. [CrossRef]

27. Kassam, A.; Bondurant, R.H.; Basu, S.; Kindahl, H.; Stabenfeldt, G.H. Clinical and endocrine responses to embryonic and fetal death induced by manual rupture of the amniotic vesicle during early pregnancy in cows. J. Am. Vet. Med. Assoc. 1987, 191, 417-420.

28. Momont, H. Rectal palpation: Safety issues. Am. Assoc. Bov. Pract. 1990, 25, 122-123. [CrossRef]

29. Day, J.D.; Weaver, L.D.; E Franti, C. Twin pregnancy diagnosis in Holstein cows: Discriminatory powers and accuracy of diagnosis by transrectal palpation and outcome of twin pregnancies. Can. Vet. J. 1995, 36, 93-97.

30. Karlsen, A.; Ruane, J.; Klemetsdal, G.; Heringstad, B. Twinning rate in Norwegian cattle: Frequency, (co)variance components, and genetic trends. J. Anim. Sci. 2000, 78, 15-20. [CrossRef]

31. Abbitt, B.; Ball, L.; Kitto, G.P.; Sitzman, C.G.; Wilgenburg, B.; Raim, L.W.; Seidel, G.E., Jr. Effect of three methods of palpation for pregnancy diagnosis per rectum on embryonic and fetal attrition in cows. J. Am. Vet. Med. Assoc. 1978, 173, 973-977.

32. Silva-Del-Río, N.; Colloton, J.D.; Fricke, P.M. Factors affecting pregnancy loss for single and twin pregnancies in a high-producing dairy herd. Theriogenology 2009, 71, 1462-1471. [CrossRef] [PubMed]

33. Curran, S.; Pierson, R.A.; Ginther, O.J. Ultrasonographic appearance of the bovine conceptus from days 20 through 60. J. Am. Vet. Med. Assoc. 1986, 189, 1295-1302. [PubMed]

34. Hughes, E.A.; Davies, D.A. Practical uses of ultrasound in early pregnancy in cattle. Vet. Rec. 1989, 124, 456-458. [CrossRef] [PubMed]

35. Taverne, M.A.M.; Szenci, O.; Szétag, J.; Piros, A. Pregnancy diagnosis in cows with linear-array real-time ultrasound scanning: A preliminary note. Vet. Q. 1985, 7, 264-270. [CrossRef] [PubMed]

36. Szenci, O.; Cyulai, G.; Nagy, P.; Kovacs, L.; Varga, J.; Taverne, M. Effect of uterus position relative to the pelvic inlet on the accuracy of early bovine pregnancy diagnosis by means of ultrasonography. Vet. Q. 1995, 17, 37-39. [CrossRef]

37. Davis, M.; Haibel, G. Use of real-time ultrasound to identify multiple fetuses in beef cattle. Theriogenology 1993, 40, 373-382. [CrossRef]

38. Del Río, N.S.; Kirkpatrick, B.W.; Fricke, P.M. Observed frequency of monozygotic twinning in Holstein dairy cattle. Theriogenology 2006, 66, 1292-1299. [CrossRef]

39. Répási, A.; Beckers, J.; Sulon, J.; Karen, A.; Reiczigel, J.; Szenci, O. Effect of the type and number of prostaglandin treatments on corpus luteum, the largest follicle and progesterone concentration in dairy cows. Reprod. Domest. Anim. 2005, 40, 436-442. [CrossRef]

40. López-Gatius, F.; García-Ispierto, I.; Hunter, R. Factors affecting spontaneous reduction of corpora lutea and twin embryos during the late embryonic/early fetal period in multiple-ovulating dairy cows. Theriogenology 2010, 73, 293-299. [CrossRef]

41. Igwebuike, U. Trophoblast cells of ruminant placentas-A minireview. Anim. Reprod. Sci. 2006, 93, 185-198. [CrossRef]

42. Peter, A.T. Bovine placenta: A review on morphology, components, and defects from terminology and clinical perspectives. Theriogenology 2013, 80, 693-705. [CrossRef]

43. Xie, S.; Low, B.G.; Nagel, R.J.; Beckers, J.-F.; Roberts, R.M. A novel glycoprotein of the aspartic proteinase gene family expressed in bovine placental trophectoderm1. Biol. Reprod. 1994, 51, 1145-1153. [CrossRef] 
44. Serrano-Pérez, B.; Garcia-Ispierto, I.; De Sousa, N.; Beckers, J.; Almeria, S.; López-Gatius, F. Gamma interferon production and plasma concentrations of pregnancy-associated glycoproteins 1 and 2 in gestating dairy cows naturally infected with Neospora caninum. Reprod. Domest. Anim. 2014, 49, 275-280. [CrossRef]

45. García-Ispierto, I.; Almería, S.; Serrano, B.; De Sousa, N.M.; Beckers, J.F.; López-Gatius, F. Plasma concentrations of pregnancyassociated glycoproteins measured using anti-bovine PAG-2 antibodies on day 120 of gestation predict abortion in dairy cows naturally infected with Neospora caninum. Reprod. Domest. Anim. 2012, 48, 613-618. [CrossRef]

46. Wooding, F.; Morgan, G.; Monaghan, S.; Hamon, M.; Heap, R. Functional specialization in the ruminant placenta: Evidence for two populations of fetal binucleate cells of different selective synthetic capacity. Placenta 1996, 17, 75-86. [CrossRef]

47. Wooding, F.B.; Morgan, G.; Adam, C.L. Structure and function in the ruminant synepitheliochorial placenta: Central role of the trophoblast binucleate cell in deer. Microsc. Res. Tech. 1997, 38, 88-99. [CrossRef]

48. García-Ispierto, I.; Rosselló-Visa, M.A.; Serrano-Pérez, B.; Mur-Novales, R.; López-Gatius, F. Plasma concentrations of pregnancyassociated glycoproteins I and II and progesterone on day 28 post-AI as markers of twin pregnancy in dairy cattle. Livest. Sci. 2016, 192, 44-47. [CrossRef]

49. Xie, S.C.; Low, B.G.; Nagel, R.J.; Kramer, K.K.; Anthony, R.V.; Zoli, A.P.; Beckers, J.F.; Roberts, R.M. Identification of the major pregnancy-specific antigens of cattle and sheep as inactive members of the aspartic proteinase family. Proc. Natl. Acad. Sci. USA 1991, 88, 10247-10251. [CrossRef]

50. Szenci, O.; Beckers, J.F.; Humblot, P.; Sulon, J.; Sasser, G.; Taverne, M.; Varga, J.; Baltusen, R.; Schekk, G. Comparison of ultrasonography, bovine pregnancy-specific protein $\mathrm{B}$, and bovine pregnancy-associated glycoprotein 1 tests for pregnancy detection in dairy cows. Theriogenology 1998, 50,77-88. [CrossRef]

51. Zoli, A.P.; Guilbault, L.A.; Delahaut, P.; Ortiz, W.B.; Beckers, J.-F. Radioimmunoassay of a bovine pregnancy-associated glycoprotein in serum: Its application for pregnancy diagnosis1. Biol. Reprod. 1992, 46, 83-92. [CrossRef]

52. Gajewski, Z.; De Sousa, N.M.; Beckers, J.F.; Pawlinski, B.; Olszewska, M.; Thun, R.; Kleczkowski, M. Concentration of bovine pregnancy associated glycoprotein in plasma and milk: Its application for pregnancy diagnosis in cows. J. Physiol. Pharmacol. Off. J. Pol. Physiol. Soc. 2008, 59, 55-64.

53. Commun, L.; Velek, K.; Barbry, J.-B.; Pun, S.; Rice, A.; Mestek, A.; Egli, C.; Leterme, S. Detection of pregnancy-associated glycoproteins in milk and blood as a test for early pregnancy in dairy cows. J. Vet. Diagn. Investig. 2016, 28, 207-213. [CrossRef] [PubMed]

54. Yániz, J.; Lopez-Gatius, F.; Garcia-Ispierto, I.; Bech-Sàbat, G.; Serrano, B.; Nogareda, C.; Sanchez-Nadal, J.; Almeria, S.; Santolaria, P. Some factors affecting the abortion rate in dairy herds with high incidence of Neospora-associated abortions are different in cows and heifers. Reprod. Domest. Anim. 2009, 45, 699-705. [CrossRef]

55. López-Gatius, F.; García-Ispierto, I. Ultrasound and endocrine findings that help to assess the risk of late embryo/early foetal loss by non-infectious cause in dairy cattle. Reprod. Domest. Anim. 2010, 45 (Suppl. S3), 15-24. [CrossRef]

56. Lopez-Gatius, F.; Santolaria, P.; Yániz, J.L.; Garbayo, J.M.; Hunter, R.H.F. Timing of early foetal loss for single and twin pregnancies in dairy cattle. Reprod. Domest. Anim. 2004, 39, 429-433. [CrossRef]

57. Semambo, D.; Eckersall, P.; Sasser, R.; Ayliffe, T. Pregnancy-specific protein B and progesterone in monitoring viability of the embryo in early pregnancy in the cow after experimental infection with. Theriogenology 1992, 37, 741-748. [CrossRef]

58. Szelényi, Z.; Répási, A.; De Sousa, N.M.; Beckers, J.F.; Szenci, O. Accuracy of diagnosing double corpora lutea and twin pregnancy by measuring serum progesterone and bovine pregnancy-associated glycoprotein 1 in the first trimester of gestation in dairy cows. Theriogenology 2015, 84, 76-81. [CrossRef]

59. Garcia-Ispierto, I.; Lopez-Gatius, F.; Santolaria, P.; Yániz, J.; Nogareda, C.; Lopez-Bejar, M.; De Rensis, F. Relationship between heat stress during the peri-implantation period and early fetal loss in dairy cattle. Theriogenology 2006, 65, 799-807. [CrossRef]

60. Bond, R.L.; Midla, L.T.; Gordon, E.D.; Welker, F.H.B.; Masterson, M.A.; Mathys, D.A.; Mollenkopf, D.F. Effect of student transrectal palpation on early pregnancy loss in dairy cattle. J. Dairy Sci. 2019, 102, 9236-9240. [CrossRef]

61. Szenci, O. Recent possibilities for the diagnosis and pharmacological control of pregnancy loss in dairy cow. J. Life Sci. 2015, 10, 171-180. [CrossRef]

62. Ricci, A.; Carvalho, P.; Amundson, M.; Fourdraine, R.; Vincenti, L.; Fricke, P. Factors associated with pregnancy-associated glycoprotein (PAG) levels in plasma and milk of Holstein cows during early pregnancy and their effect on the accuracy of pregnancy diagnosis. J. Dairy Sci. 2015, 98, 2502-2514. [CrossRef] [PubMed]

63. Andreu-Vázquez, C.; Garcia-Ispierto, I.; López-Béjar, M.; de Sousa, N.; Beckers, J.; López-Gatius, F. Clinical implications of induced twin reduction in dairy cattle. Theriogenology 2011, 76, 512-521. [CrossRef] [PubMed]

64. Andreu-Vázquez, C.; Garcia-Ispierto, I.; López-Gatius, F. Manual rupture versus transvaginal ultrasound-guided aspiration of allanto-amniotic fluid in multiple pregnancies: A clinical approach to embryo reduction in dairy cattle. J. Reprod. Dev. 2012, 58, 420-424. [CrossRef] [PubMed]

65. López-Gatius, F. Twins in dairy herds. is it better to maintain or reduce a pregnancy? Animals 2020, 10, 2006. [CrossRef] [PubMed]

66. Garcia-Ispierto, I.; López-Gatius, F. The effects of a single or double GnRH dose on pregnancy survival in high producing dairy cows carrying singletons or twins. J. Reprod. Dev. 2018, 64, 523-527. [CrossRef] 
67. Cabrera, V.E.; Fricke, P.M. Economics of twin pregnancies in dairy cattle. Animals 2021, 11, 552. [CrossRef]

68. Szelényi, Z.; Balogh, O.G.; Lopez-Gatius, F.; Garcia-Ispierto, I.; Krikó, E.; Gábor, G. Is twin pregnancy, calving and pregnancy loss predictable by serum pregnancy-specific protein $\mathrm{b}(\mathrm{pspb})$ concentration $28-35$ days after ai in dairy cows? Acta Vet. Hung. 2018, 66, 451-461. [CrossRef] 